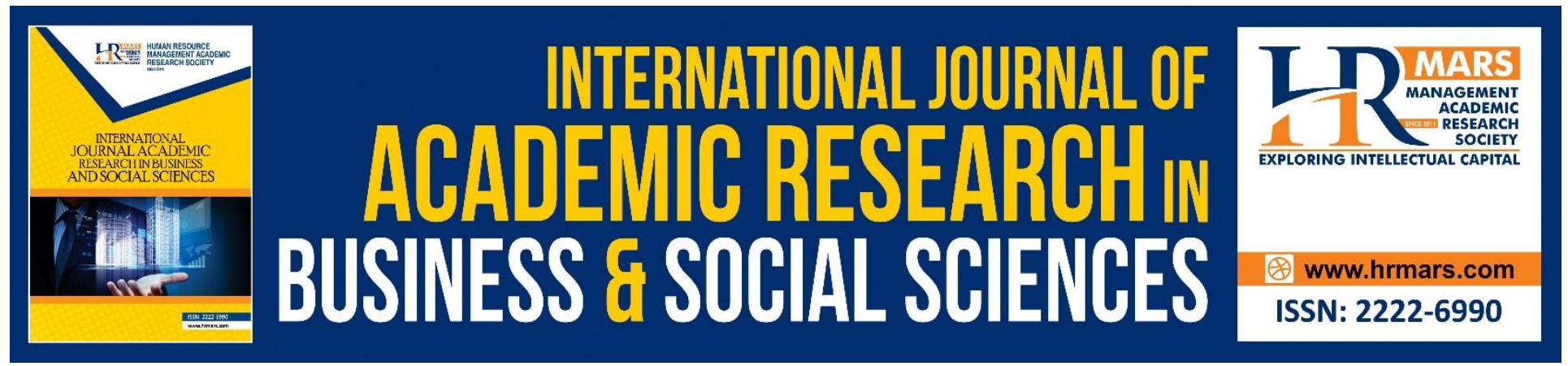

\title{
Exploring Capacity of Middle Managers as Instructional Leadership to Lead Transformations of Teaching and Learning in Malaysian High Performing Schools
}

Abdul Ghani Kanesan Abdullah, Abdul Jalil Ali, AlAmin Mydin \& Nor Aiza Zamzam Amin

To Link this Article: http://dx.doi.org/10.6007/IJARBSS/v9-i3/5773

DOI: $10.6007 /$ IJARBSS/v9-i3/5773

Received: 1 Jan 2019, Revised: 15 Feb 2019, Accepted: 29 Feb 2019

Published Online: 13 March 2019

In-Text Citation: (Abdullah, Ali, Mydin, \& Amin, 2019)

To Cite this Article: Abdullah, A. G. K., Ali, A. J., Mydin, A., \& Amin, N. A. Z. (2019). Exploring Capacity of Middle Managers as Instructional Leadership to Lead Transformations of Teaching and Learning in Malaysian High Performing Schools. International Journal Academic Research Business and Social Sciences, 9(3), 1132-1142.

Copyright: (C) 2019 The Author(s)

Published by Human Resource Management Academic Research Society (www.hrmars.com)

This article is published under the Creative Commons Attribution (CC BY 4.0) license. Anyone may reproduce, distribute, translate and create derivative works of this article (for both commercial and non-commercial purposes), subject to full attribution to the original publication and authors. The full terms of this license may be seen

at: http://creativecommons.org/licences/by/4.0/legalcode

Vol. 9, No. 3, 2019, Pg. 1132 - 1142

http://hrmars.com/index.php/pages/detail/IJARBSS

JOURNAL HOMEPAGE

Full Terms \& Conditions of access and use can be found at http://hrmars.com/index.php/pages/detail/publication-ethics 


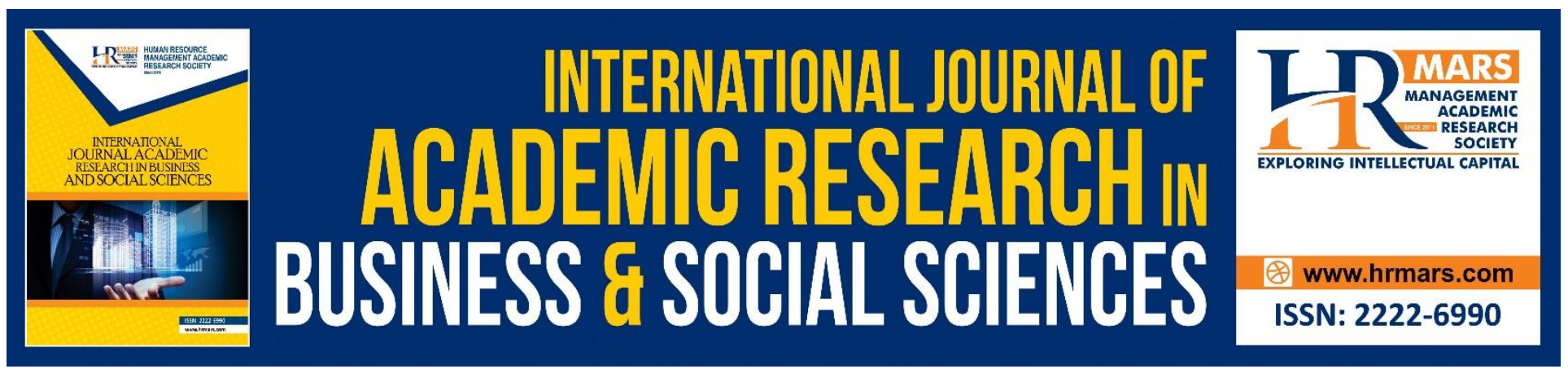

\title{
Exploring Capacity of Middle Managers as Instructional Leadership to Lead Transformations of Teaching and Learning in Malaysian High Performing Schools
}

\author{
Abdul Ghani Kanesan Abdullah \\ Lecturer, Universiti Sains Malaysia, Penang \\ Abdul Jalil Ali \\ Lecturer, Universiti Sains Malaysia, Penang \\ AlAmin Mydin \\ Lecturer, Universiti Sains Malaysia, Penang
}

\author{
Nor Aiza Zamzam Amin \\ Lecturer, Kolej Matrikulasi Perak
}

\begin{abstract}
Since 2013, the Malaysian Education Development Planning Plan 2013-2025 (PPPM) has been and is being implemented to drive the nation's education transformations. Therefore, recent studies suggest in making sure that effective instructional leadership is being practiced in schools, principals should share the instructional leadership functions with the school middle managers. Thus, the current study sought to expand on these earlier studies by examining the capacity of Malaysia's middle managers as instructional leadership to lead transformations in teaching and learning. The study developed a national profile of middle managers instructional leadership from 400 high performing school teachers' perspectives using the Principal Instructional Management Rating Scale. The overall profile of location urban and region (North, Central, South, and East) middle managers suggested a moderate level of engagement in instructional leadership. However, there was a higher engagement revealed in instructional leadership by middle managers in rural schools especially in Central, South and East region of Peninsular Malaysia. The results provide evidence which suggests that a more systematic human resource strategy is needed in order to ensure that Malaysian
\end{abstract}


INTERNATIONAL JOURNAL OF ACADEMIC RESEARCH IN BUSINESS AND SOCIAL SCIENCES

Vol. 9, No. 3, March, 2019, E-ISSN: 2222-6990 @ 2019 HRMARS

principals should highly share and empower the duty as instructional leaders among the middle managers to support changes in teaching and learning.

Keyword: Malaysian Middle Managers, Instructional Leadership, Teaching And Learning, Improvement.

\section{Introduction}

The 2000s were a decade of active education reform throughout the world (Hanushek \& Woessmann, 2007) and the provision of quality education systems is a platform to meet the demands of the world's 21st-century economic, social and political challenges in either developed countries as well as developing countries such as Malaysia (Alimuddin, 2009). Recognizing that healthy socio-cultural development and sustained economic development depend on the ability to improve the success of the national education system, the Malaysian government has undertaken various policy changes and educational transformations since then. Recently, the Malaysian Education Development Planning Plan 2013-2025 (PPPM) has been and is being implemented to drive the nation's education towards quality and international education based on five key aspects of aspiration namely the access, quality, equity, unity, and efficiency. Therefore, in realizing the PPPM 2013-2025's aspirations as well as driving schools towards effective schools, and principals in Malaysia are required to play various roles (Sim, 2011) especially instructional leadership more actively as it relates to school achievement (Ibrahim, Sani \& Rosemawati, 2015; Yusri \& Amin, 2014; Jamilah \& Boon, 2011). Meanwhile, PPPM 2013-2025 also aims to bridge the gap between education (urban and rural), socioeconomics and student capability so that access, equity, and quality can be enhanced either from the aspect of locations such as urban and rural gaps, technology gaps, gaps between student achievement levels, gaps between normal students and special needs students and socioeconomic gaps (MOE,2012)

In the context of school leadership in Malaysia, schools are led by principals, however, principals do not have enough time to practice instructional leadership because they are too occupied with the responsibilities of running the schools. Therefore, in making sure that effective instructional leadership is being practiced in schools, principals should share the instructional leadership functions with the school middle managers (Hall \& Hord, 2001). Furthermore, the current leadership trends no longer see school leaders assuming all responsibilities as instructional leaders alone. Harris (2002) emphasizes that the leadership trends are not just focusing on the ability, skills or talents of individuals but rather on focusing on how to create a culture of shared responsibility in the organization. Therefore, the responsibilities as instructional leaders have to be shared among members especially with middle managers in the organization because middle managers to have knowledge and experience needed, particularly in the context of teaching and learning (James \& Balasandran, 2009). As Solomon (2007) concludes that school middle managers have to play a critical role in maintaining the commitment of the teacher by giving more attention to personal and school context factors.

This sets the context for the present study which examined the instructional leadership capacity of Malaysian high performing school middle managers during this decade of education transformation. The research sought to assess the extent to which the instructional leadership 
capacity of Malaysian middle managers has met the requirements' education transformations in teaching and learning. Therefore, the aim of this study is to answer the following research questions:-

a. What is the overall pattern of instructional leadership exercised by Malaysian's middle managers in high performing schools?

b. Are there differences in the pattern of instructional leadership exercised by Malaysian's middle managers in high performing schools at different location and region level?

\section{Instructional Leadership of Middle Managers in Malaysian Context}

The concept of instructional leadership has been studied extensively since the 1980s and 1990s. Instructional leadership refers to all actions and activities undertaken by a principal to strengthen the implementation process of teaching and learning. According Hallinger and Murphy (1985), instructional leadership is any activity undertaken by school administrators to enhance the success of the process of teaching and learning and school development. For the Malaysian context, the importance of curriculum management through instructional leadership practice is one of the nine competencies highlighted in Malaysian School Principalship Standard Competency introduced by the Ministry of Education (MOE, 2006). Nevertheless, the importance of principal as instructional leadership is clearly stated in the Professional Circular No. 3/1987 that the primary responsibility of the principal or headmaster is to ensure the successful implementation of the curriculum in schools. Thus, the implementation of the curriculum and activities at the school level is carried out through the process of teaching and learning by teachers through rigorous and systematic supervision of the principal.

In the Malaysian school context, the duties of middle managers in the public secondary schools are directly involved in the curriculum. They would take over the duty of the principal when the principal is not in school. They have to teach several hours, helping students relate to their academic programmes and mentoring the students' activities. Sim (2011), highlighted that the middle managers are also responsible for improving the teaching process by giving direct guidance to teachers and encouraging in-house training. Thus, by involving directly with curriculum, the middle managers are actually already practicing instructional leadership functions.

While the presence of empowerment at the school level, middle managers in Malaysian schools are responsible for shaping the learning climate directly and indirectly by protecting instructional time, selecting and participating in high-quality teacher development programmes consistent with the school mission and promoting incentives to teachers and learning (Rahmat, 2010; Premavathy 2010). In managing instructional activities, the middle managers have to make sure that teaching and learning are being supervised, the curriculum is being coordinated and, student learning is being monitored. For developing a positive school learning climate, they have to protect instructional time, providing incentives for teachers and students, maintain visibility, and promoting professional development. In short, school middle managers have to ensure that teachers are given the chance to improve their instructional practices. By giving the middle managers the opportunity to play the role of instructional leadership, it can help to sustain the success of the school. Therefore, these study hypotheses that school middle managers in secondary schools in Malaysia would have to carry out the functions of instructional leadership in helping teachers to increase teacher performance. 


\section{Hallinger and Murphy Instructional Leadership Model in the Malaysian Context}

Various models of instructional leadership have evolved in the context of Malaysia such a Hallinger and Murphy (1985), Murphy (1990), Krug (1992), Hussein Mahmood (1997), Weber (1999) and lastly James and Balasandran (2009). And obviously, these models have featured in common though expressed in different ways. However, Hallinger and Murphy (1985) model are the most frequently used in research on instructional leadership, especially in the Malaysian school setting. According to Hallinger and Murphy (1985) model, instructional leadership behavior has three main dimensions, namely Creating Mission, Managing Instruction, and creating a climate of learning to improve teaching and learning in schools.

The studies related to instructional leadership using Hallinger and Murphy (1985) model have been widely carried out in Malaysia, for example, Kean, Sathiamoorthy and Chua (2017), Safinaz, Chua, Wei and Shahrin (2016), Hui and Jamal(2016), Zakaria and Sufien (2016), Baharuzaini, Hisham, Hanif, Norhisyam and Norhaini (2016), Yusri and Amin (2014), Aniza and Zaidatol (2014) and many others have discovered the principal of the school in Malaysia that practices with effective instructional leadership have a positive impact on school learning organization, committed teachers, teaching quality and academic performance of students.

However, these studies are done mainly on the instructional leadership of the principals, and very little discussion is done on the role of the school middle managers particularly. As Hallinger (2005) also proclaims that discussion on instructional leadership as a shared functions, reference made to teachers, head of the department or even the middle managers as instructional leaders are very limited.

\section{Method}

\section{Population and Sample}

The population for this study was public secondary school teachers randomly selected from Peninsular Malaysia using cluster sampling from four regions/zone namely northern, central, southern and east of Peninsular by applying the multi-stage sampling method. The multi-stage sampling is a combination of cluster random sampling with individual random sampling. In this study, a cluster refers to schools in the four zones, and individuals refer to teachers teaching in schools in these zones. In the first stage, all the states in Peninsular Malaysia were clustered into four zones, and the schools were randomly selected from each zone. In the second stage, the desired sample size was determined. After determining the sample size, the next stage was to determine the required number of schools in each zone. A ratio calculation was used based on the number of schools in each zone and the total number of schools from all the zones. Finally, in the final stage, 10 teachers from each school were randomly selected from the list of names of teachers in the schools. In total 400 teachers from 40 schools participated in this study and the distribution of respondent demographics are shown in Table 1 below. 
INTERNATIONAL JOURNAL OF ACADEMIC RESEARCH IN BUSINESS AND SOCIAL SCIENCES

Vol. 9, No. 3, March, 2019, E-ISSN: 222 2-6990 @ 2019 HRMARS

Table 1 :Profile of Respondents

\begin{tabular}{|c|c|c|c|c|}
\hline Demographic Variables & Categories & & Frequencies & Percentage \\
\hline \multirow[t]{2}{*}{ Gender } & Male & & 142 & 35.5 \\
\hline & Female & & 258 & 64.5 \\
\hline \multirow[t]{4}{*}{ Region/zone } & Northern & & 98 & 24.7 \\
\hline & Central & & 108 & 27.0 \\
\hline & Southern & & 97 & 24.3 \\
\hline & East & & 96 & 24.0 \\
\hline \multirow[t]{3}{*}{ Location } & Rural & & 170 & 42.5 \\
\hline & Urban & & 230 & 57.5 \\
\hline & Mean & SD & Min & Max \\
\hline Age (years) & 40.55 & 5.1 & 26 & 58 \\
\hline $\begin{array}{l}\text { Years of Teaching experience in } \\
\text { current school }\end{array}$ & 7.20 & 5.14 & 2 & 26 \\
\hline Years of Teaching experience & 14.91 & 7.93 & 2 & 36 \\
\hline
\end{tabular}

\section{Instrumentation}

Middle managers Instructional Leadership practice were measured using a 30-item instrument, adapting the Principal Instructional Management Rating Scale - Teacher Form 2.0 (Hallinger \& Murphy, 1987). The Principal Instructional Management Rating Scale (PIMRS) is the most commonly used instrument for studying instructional leadership. Hallinger (2008) in his review on methodologies for studying school leadership reports that PIMRS has been used in over 119 studies since its development in 1982. This section is to obtain teachers' perception of instructional leadership exhibited by the middle managers in their schools respectively. However, it should be noted that the high score on PIMRS only indicates active leadership in those areas. It does not indicate the quality of that leadership (Hallinger \& Murphy, 1987). All the items in this instrument were positively worded.

\section{Analysis Method}

Three main methods of data analysis have been used to address the three research question. First, descriptive statistics were used to develop profiles of the principals on the three instructional leadership dimensions. These describe the national profile of Malaysian middle managers on the three instructional leadership dimensions with breakdowns by location and region level. Next, for the second research questions, t-test and MANOVA were deployed accordingly.

\section{Findings}

In the first step in data analysis, the overall profile of the middle managers' instructional leadership practice on the three PIMRS dimension was developed. As Table 2 revealed that there is a highly moderate level of engagement in instructional leadership on three dimensions in North, Central, South and East region. However, there was a higher engagement revealed in instructional leadership by middle managers in rural schools especially in Central, South and East region of Peninsular Malaysia. 
INTERNATIONAL JOURNAL OF ACADEMIC RESEARCH IN BUSINESS AND SOCIAL SCIENCES

Vol. 9, No. 3, March, 2019, E-ISSN: 222 2-6990 @ 2019 HRMARS

Table 2:Descriptive findings of instructional leadership by location and region level

\begin{tabular}{|l|c|c|c|c|c|c|c|c|}
\hline & \multicolumn{4}{|c|}{ Urban } & \multicolumn{4}{c|}{ Rural } \\
\hline & North & Central & South & East & North & Central & South & East \\
\hline Creating Mission & 4.09 & 3.85 & 4.05 & 3.95 & 3.95 & 4.11 & 4.04 & 4.04 \\
\hline Managing Instruction & 4.07 & 3.85 & 4.06 & 3.98 & 3.94 & 4.08 & 4.07 & 4.00 \\
\hline $\begin{array}{l}\text { Developing Learning } \\
\text { Climate }\end{array}$ & 4.25 & 3.86 & 4.06 & 3.96 & 4.05 & 4.14 & 4.05 & 4.08 \\
\hline
\end{tabular}

Further analysis of variation in the three dimensions of middle managers' instructional leadership by focusing on the school context in which they worked was deployed. Figure 1 illustrates patterns of variation by location and region level.
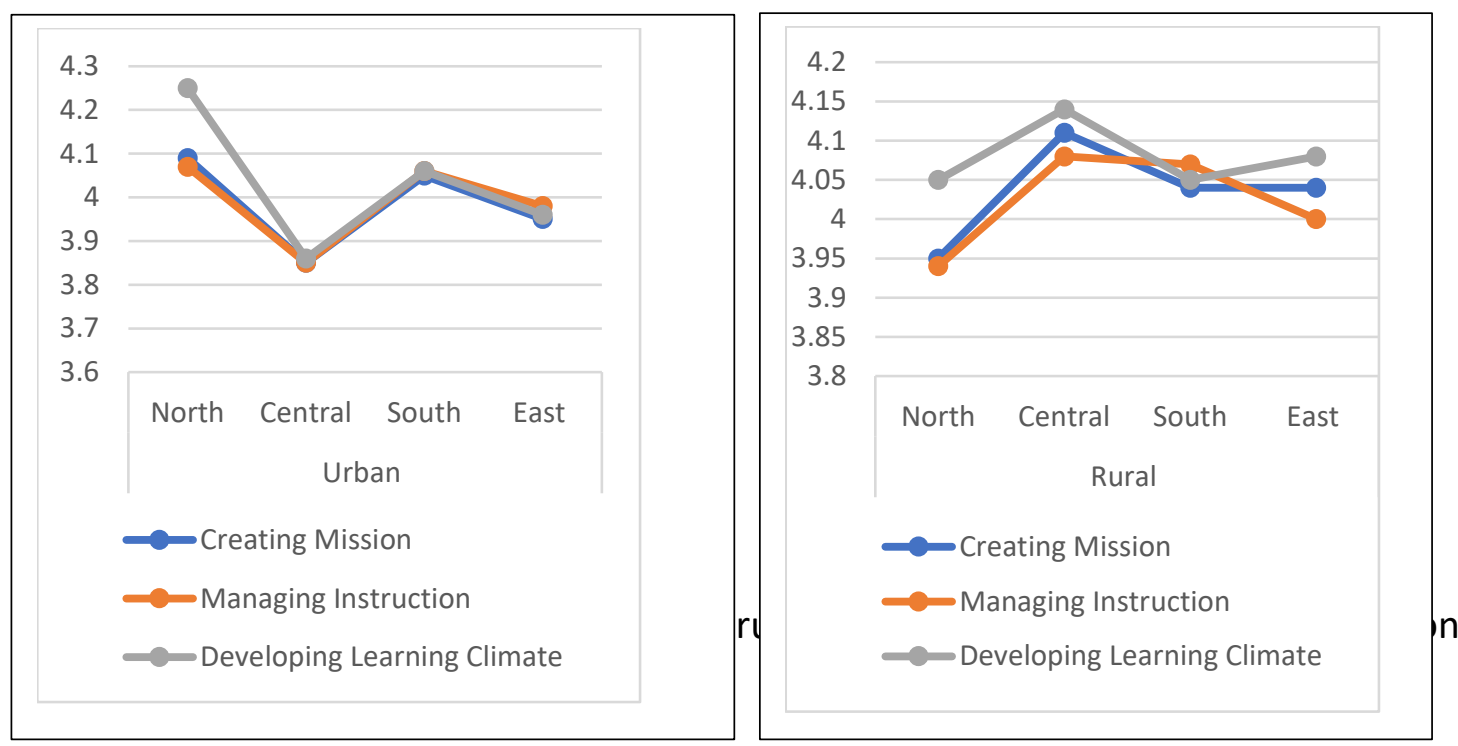

\section{Analysis of Instructional Leadership by Location}

Application of t-test revealed that there are no significant differences in the pattern of association for the three Instructional Leadership dimensions and school location. Thus, school location appeared not to be associated with MM's Instructional Leadership practice at least in Malaysian urban and rural schools.

Table3: T-test findings of instructional leadership by location

\begin{tabular}{|c|c|c|c|c|c|}
\hline & & Mean & mean & T value & pvalue \\
\hline \multirow[t]{2}{*}{ Creating Mission } & Urban & 3.95 & .55 & -1.75 & .18 \\
\hline & Rural & 4.04 & .42 & & \\
\hline \multirow[t]{2}{*}{ Managing Instruction } & Urban & 3.96 & .51 & -.86 & .67 \\
\hline & Rural & 4.00 & .41 & & \\
\hline \multirow{2}{*}{$\begin{array}{l}\text { Developing } \\
\text { Climate }\end{array}$} & Urban & 3.96 & .51 & -1.38 & .29 \\
\hline & Rural & 4.03 & .40 & & \\
\hline
\end{tabular}




\section{Analysis of Instructional Leadership by Region}

Next MANOVA with bootstrapping was used to explore patterns of Instructional Leadership in each Malaysian four geographical regions. The results revealed that all the four different statistical tests (Pillai's Trace, Wilk's Lamda, and Hoteling's trace all indicated $p=.422$; meanwhile Roys's Largest Root indicated $p=.134$ ) were not significant. Thus, these results suggested that $M M^{\prime}$ 's are practicing the same amount of IL dimensions in the four regions of Malaysia.

\section{Discussions}

This study found that the majority of teachers perceived that their middle managers practice on instructional leadership was moderate. This implies that most teachers felt that the responsibility of carrying out the function as instructional leaders in school was still being dominant by the principals. Indirectly, this finding shows that principals in schools did not fully delegate the instructional tasks within the middle managers in their schools. In other words, it can be suggested that distributed leadership was not fully practiced by the principals. This finding is supported by Kean, Sathiamoorthy, and Chua (2017), and Safinaz, Chua, Wei and Shahrin (2016) research who found that principals were still actively engaged in being an instructional leader in their schools. Therefore, the middle managers in Malaysian secondary schools were not given the authority to practice their role as an instructional leader fully.

Interestingly, the finding also shows that most teachers perceived that their middle managers were more concerned with developing a positive learning climate compared to managing the instructional programme and creating a mission. In other words, the middle managers were focussing more on the culture of learning, whereby both teachers and students were learning to improve the teachers' instructions and the quality of student learning. This finding matches with Baharuzaini, Hisham, Hanif, Norhisyam and Norhaini (2016), Yusri and Amin (2014), Aniza and Zaidatol (2014) finding that it was the responsibilities of the school leaders to develop a learning community, whereby all members are capable of learning new skills and knowledge continuously. Thus, the senior assistants of administration to take the culture of learning seriously.

Practically, the three most active instructional leadership tasks performed by these middle managers were providing incentives for learning, coordinating curriculum and protecting instructional time. One possible explanation for this is that the school middle managers were more concerned with the process of teaching and learning. They were aware that it is important to provide incentives for learning to acknowledge the students' effort. It is also important to spend more time on coordinating curriculum and to ensure that teachers use the instructional time to the fullest. This finding concludes that the focus of the nowadays middle managers is more on learning compared to other dimensions of instructional leadership.

\section{Implications}

The results of this study could provide several theoretical perspectives on the Malaysian education setting. Firstly, the present research has enriched the body of knowledge on instructional leadership in the Malaysian educational setting with regards to the role played by the school middle managers. Many studies on instructional leadership have shown that principals are able to play their roles as instructional leaders, but this study has also revealed that the middle managers too are also capable 
to be instructional leaders. This contributed to the theory of instructional leadership by Hallinger and Murphy (1990) in terms of managing the instructional programme and developing a positive school learning climate.

Therefore, the results of this study could provide several theoretical perspectives on the Malaysian education setting. Firstly, the present research has enriched the body of knowledge on instructional leadership in the Malaysian educational setting with regards to the role played by the school middle managers. Many studies on instructional leadership have shown that principals are able to play their roles as instructional leaders, but this study has also revealed that the middle managers too are also capable to be instructional leaders. This contributed to the theory of instructional leadership by Hallinger and Murphy (1990) in terms of managing the instructional programme and developing a positive school learning climate.

Practically, the opportunity of the middle managers in practising the role as an instructional leaders could enhance their self-confidence and self-esteem in becoming an efficient leader in the future. Most importantly, the principals themselves should have the confidence that their middle managers are able to carry out the responsibilities as instructional leaders, and thus, share the responsibility together with the middle managers. In addition, by focussing more on the role of instructional leadership, this could make the middle managers aware that their role is not being a manager, but more as instructional leaders. The Ministry of Education and policymakers could perhaps conduct professional development for the middle managers to ensure that they are always being updated with the knowledge of being an instructional leader.

\section{Conclusion}

It can be conclude that the findings of this study contribute to our understanding of the role of instructional leadership of the middle managers especially in Malaysian settings. Principals cannot perform as instructional leaders alone, and they need the help nurture middle managers as instructional leaders which in turn could influence teacher commitment and school performance.

\section{Reference}

Alimuddin, M. D. (2009), Instructional Leadership: Principal and teachers' role in enhancing quality of teaching and learning in classroom. Putrajaya: Kuala Lumpur.

Aniza, B., \& Zaidatol, A. L. P. (2014).Principals' instruksional and transformational leadership practices and its relationship with school performance. Journal of Educational Leadership and Management, 28(02), 107-121.

Baharuzaini, B, Hisham,M. A., Hanif,M. Z., Norhisyam,M. K., \& Norhaini,A.M. (2016). Headteachers' leadership style and teachers' efficacy. Journal of Personalized Learning, 2(1) 2016, 9-17.

Hanushek, E. A., \& Woessman, L. (2007). The Role of Education Quality for Economic Growth, World Bank Policy Research Working Paper No. 4122

Hall, G. E., \& Hord, S. M. (2001). Implementing Change: Patterns, Principles, and Potholes. Boston: Prentice Hall.

Hallinger, P. (1990). Principal Instructional Management Rating Scale. Sarasota, FL: Leading Development Associates. 
INTERNATIONAL JOURNAL OF ACADEMIC RESEARCH IN BUSINESS AND SOCIAL SCIENCES

Vol. 9, No. 3, March, 2019, E-ISSN: 222 2-6990 @ 2019 HRMARS

Hallinger, P. (2005). Instructional Leadership and the School Principal: A Passing Fancy that Refuses to Fade Away. Leadership \& Policy in Schools, 4(3), 221-239.

Hallinger, P., \& Murphy, J. F. (1985). Assessing the instructional management behaviors of principals. The Elementary School Journal, 86(2), 217-247.

Hallinger, P., \& Murphy, J. F. (1987). Assessing and Developing Principal Instructional Leadership. Educational Leadership Journal, 45(1), 54-61.

Harris, A. (2002). Distributed Leadership in Schools: Leading or misleading? Management in Education, 16(5), 10-13.

Hui,L.S., \& Jamal, Y. (2016). Instructional leadership practices, organizational culture and organizational learning in Malaysian high performing schools. Journal of Educational Leadership and Management, 30(02), 1-19.

Ibrahim, K. A, Sani, M. I., \& Rosemawati, M (2017). Instructional leadership competency among school principal: An empirical study in Selangor. Journal of Educational Leadership, 2(3),1-14

James, A. E., \& Balasandran, R. (2009). Instructional leadership: A practical guide. Kuala Lumpur: PTS Professional.

Jamilah, A., \& Boon. Y. (2011). Leadership practices in Malaysian high performing schools. Journal of Edupress, 1, 323-335.

Mahmood, H. (2008). Leadership and school effectiveness (2 Ed.). Kuala Lumpur: Dewan Bahasa dan Pustaka.

Krug, S. E. (1992). Instructional Leadership: A Constructivist Perspective. Educational Administration Quarterly, 28, 430-443

Ministry of Education. (2012). Malaysia Education Blueprint 2013-2025: Preliminary Report Executive summary.Putrajaya:Kuala Lumpur

Murphy, J. (1990). Principal instructional leadership. In R. S. Lotto \& P. W. Thurston (Eds.), Advances in educational administration: Changing perspective on the school (Vol. 1,Pt. B, pp. 163-200). Greenwich, CT: JAI.

Premavathy, P. (2010). The relationship of instructional leadership, teachers' organizational commitment and students' achievement in small schools. Master's Thesis, Universiti Sains Malaysia, Pulau Pinang.

Solomon, C. B. (2007). The relationships among middle level leadership, teacher commitment, teacher collective efficacy, and student achievement. Ph.D. Thesis, University of Missouri - Columbia.

Kean, H.T., Sathiamoorthy, K, \& Chua, Y. P. (2017), the Effect of School Bureaucracy on the Relationship between Principals' Leadership Practices and Teacher Commitment in Malaysia Secondary Schools. Malaysian Online Journal of Educational Sciences, 5 (1): 37-55.

Shafinaz, A. M., Chua, Y. P, Wei,L.M., \& Alias,S. (2016). Principals' instructional leadership and its relationship with teachers self eficacy. Journal of Educational Leadership and Management, 30(02), 73-92.

Sim, Q, C. (2011). Insructional leadership among principals of secondary schools in Malaysia. International Research Journal. 2, 1784-1800.

Weber, J. (1996). Leading the instructional program. In S. Smith \& P. Piele (Eds.), School leadership (pp. 253-278). Eugene, OR: Clearinghouse of Educational Management. 
INTERNATIONAL JOURNAL OF ACADEMIC RESEARCH IN BUSINESS AND SOCIAL SCIENCES

Vol. 9, No. 3, March, 2019, E-ISSN: 222 2-6990 @ 2019 HRMARS

Yusri,M. I \& Amin,A. (2017), Principals' instructional model and teachers' teaching competency, Asia Pacific Journal of Curriculum and Teaching, 2(1), 2289-3008.

Zakaria,O., \& Sufien, H. (2016). Head masters' instructional leadership and its relationship with academic performance in under enrollment schools. Journal of Educational Leadership and Management, 29(01), 61-86. 